\title{
Seismic behavior of Mudejar structures
}

\author{
J. Ruiz Jaramillo \\ Department of Architectural Construction. University of Malaga. Malaga, Spain
}

A. Jaramillo Morilla \& E. Mascort Albea

Department of Building Structures and Geotechnical Engineering, University of Seville, Seville, Spain

doi: 10 14575/g1/rehab2014/099

\begin{abstract}
Intensive seismic events show the particular impact of these actions in the destruction of the built heritage. The Mudejar architecture has been analysed from the standpoint of the structural behaviour under seismic actions, trying to verify the response of these buildings if today they needed to face an earthquake. Dynamic analysis in situ of the structural rigidity is proposed for the seismic design, protection and rehabilitation of existing structures. This method makes possible the knowledge of the building, contributing to the restoration works through the proposal of specific constructive solutions according to the particularities of each building.
\end{abstract}

\section{INTRODUCTION}

\subsection{The Mudejar style}

From the thirteenth century with the Christian reconquest of the Bajo Guadalquivir can be considered that the Gothic style of the Christian conquerors is expanded throughout the Iberian Peninsula. This style met with a strong Islamic architectural tradition, so its assimilation is not immediate. Being a stranger to the local tradition, for its survival is forced to combine with Islamic art pre-existing generating the peculiar style called Mudejar, named in relation to the arabic population that remained their religion while they lived in Christian territory.

Within the Community of Andalusia, this style has its main importance in the provinces of Córdoba and Seville, mainly used after the reconquest in the construction of the new representative, especially religious buildings. In these, the Gothic style imposed defines the new epicenter of religious space through its presence for example in the polygonal chancel of the temples. The rest of constructive elements it remains under walls and a wooden roof generated under different constructive tradition (Islamic), being structured these elements in most cases, as a response to existing conditions (Angulo, 1983).

Like in other European countries, the south of Spain has a high seismic risk. This is shown, for example, by the seismic events with intensity up to VI (MSK) that the city of Seville has suffered along its history.

In the fourteenth century, August $24^{\text {th }}, 1356$, an earthquake of intensity VIII occurred at southwest of Cape St. Vincent, having a great effect in the city of Seville. In this sense, it cannot 
be forgotten that according to current seismic code, Seville is located in a moderate seismic risk zone (García, 2002). Consequently, the parishes erected after the conquest had to be repaired or rebuilt, initiating a constructive period for religious architecture in Seville that extended until the early fifteenth century.

History shows us that earthquakes of similar intensity (about VIII (EMS)) can take place in Andalusia, such as the previously mentioned earthquake of 1356,1504 or the so called "Lisbon earthquake" in 1755 which affected seriously the buildings of Seville.

Since the Mudejar churches architecture generated in the city after the conquest form a large and homogeneous group, they have been analyzed from the standpoint of the structural behavior under seismic actions, trying to verify the response of these buildings if today they needed to face an earthquake of similar characteristics to the specified.

This means, one of the most constructive typologies of the city of Seville that have remains until today is confronted with the seismic events that they have suffered along its history.

\subsection{Heritage preservation and seismic risk}

The destructive action of seismic events on heritage has been sufficiently demonstrated recently. On April 6, 2009 occurred in the Italian town of L'Aquila an earthquake of 6,7 degrees in the Richter scale. There were a total of 294 deaths, in addition to significant damage to the built heritage in it. The earthquake had a particular impact on the destruction or serious damage of buildings with great historical value: palaces and churches built during the Renaissance and Baroque, most of them considered World Heritage. In 2011 in Spain we could experience something similar with the earthquake of May 11, which partially destroyed the city of Lorca. Besides to the terrible personal loss, damages on the built heritage of the town were very important.

If we analyse the concept of heritage this is inextricably linked to the memory of a nation, physically represented by its iconic buildings, symbol of identity and cohesion or identification elements of their respective communities. Thus, the destruction caused by these natural disasters comes to exceed its historical value and its aesthetic dimension. We have in Iquique (Chile) an example of the losing touch caused by the loss of heritage. There was the Tarapaca earthquake in 2005 which result in large losses of human lives and destruction of paradigmatic buildings as the Church of San Lorenzo (built in 1723) declared World Heritage. The people said to the president of the country during his visit to the area "I do not care about my house, but I want to get my Church". Also, in the Mexican state of Oaxaca, after the 1999 earthquake, the majority of rural communities preferred first the restoration of their temples that their own homes, sometimes in worse condition and even dangerous for the lives of its occupants.

Since the second half of the twentieth century there is in Spain a mandatory seismic regulations. But, if in spite of its existence we find a manifest breach of its guidelines (in this sense, it is enough looking at the event of Lorca where the most of damage buildings were newly constructed), it is compulsory to ask about what is happening the architecture of historic character and heritage?

\section{CHARACTERIZATION OF THE TYPE OF STUDY}

\subsection{Constructive definition}

A total number of 18 Mudejar churches of Seville built in that period have been analysed as a basis for this study. Making a comparison between the different elements that make up the sample has been possible to generate a model which summarizes the main characteristics of all models analysed.

The type of study consists of a structure with four bearing walls of brick that configures three naves covered by a wooden couple-close roof with decorative tracery of different designs. The lateral naves are covered by a single wooden pitch roof. The end of the three naves in the chancel is solved by incorporating a polygonal head (also built with brick, like the lateral bearing walls) with the presence of Gothic buttresses on the outside and ribbed vaulted roof inside. The 
wall separating the nave from the aisles is materialized by pointed arches on pillars, which are also built in brick (Cómez, 1974).
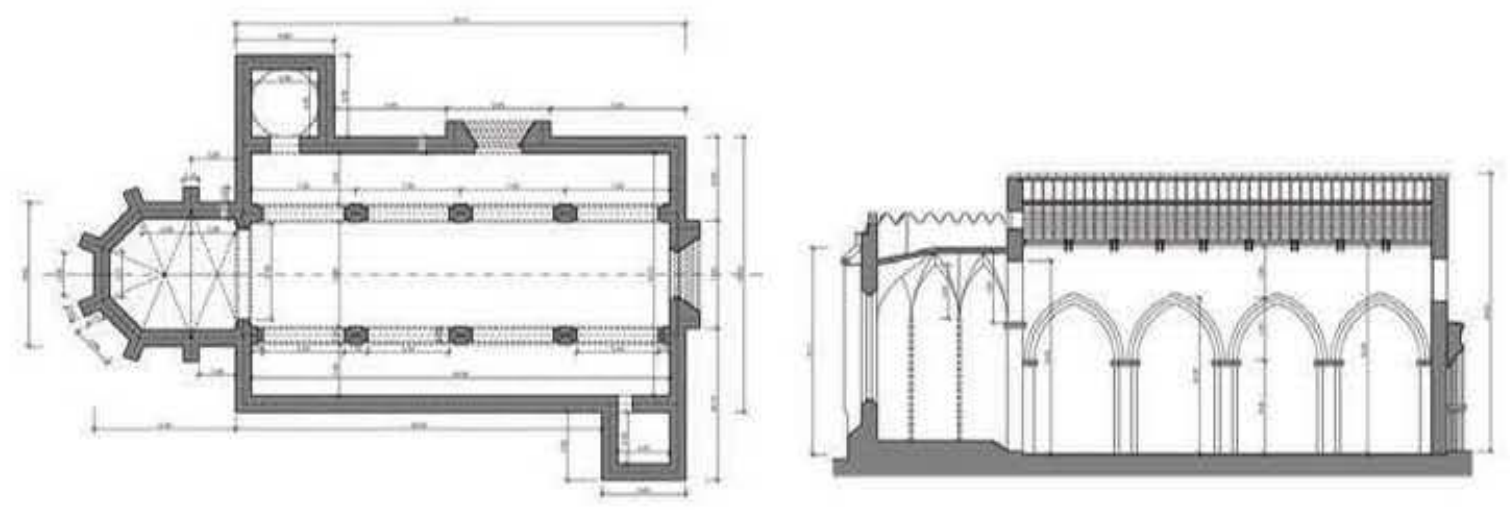

Figure 1. Plan and section fo the type. Source: author.

Other features that configures the type are the front stone factory, located ending the central nave in the gable wall and on the side of the Epistle nave, and the side chapel with its vaulted brick and the tower usually located joining to the wall of the feet.
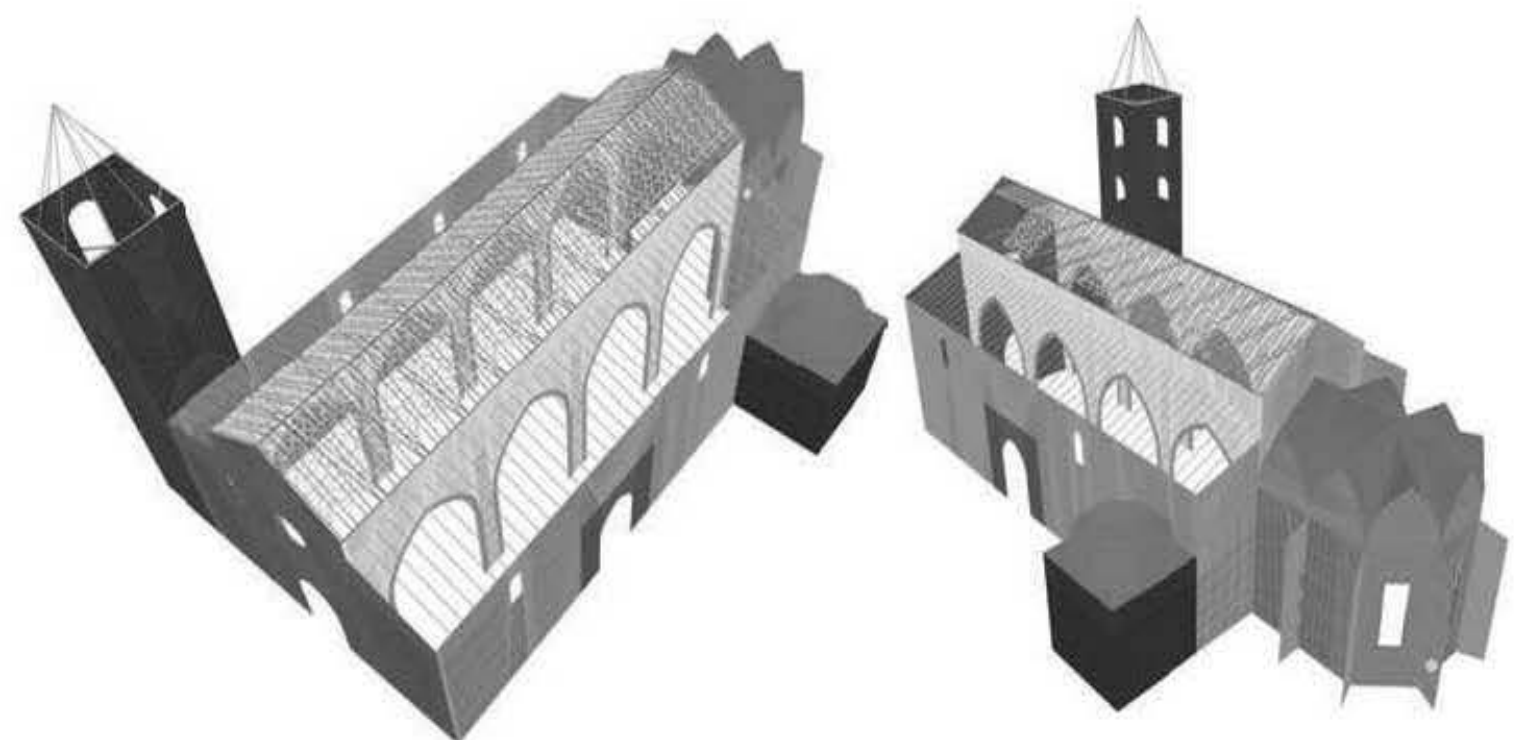

Figure 2. 3D model of the type. Source: author.

\subsection{Specific damages of the constructive type.}

Once defined the type and components that define it, we must have an impact on the most common damages that presents because they will have an impact on the structural behaviour. The professor Vigil-Escalera already made in 1991 a catalogue of typical damages of this constructive type (Vigil-Escalera, 1991). The most of them have appeared again after the restoration that has been carried out in many of them in the latest years of twentieth century. 

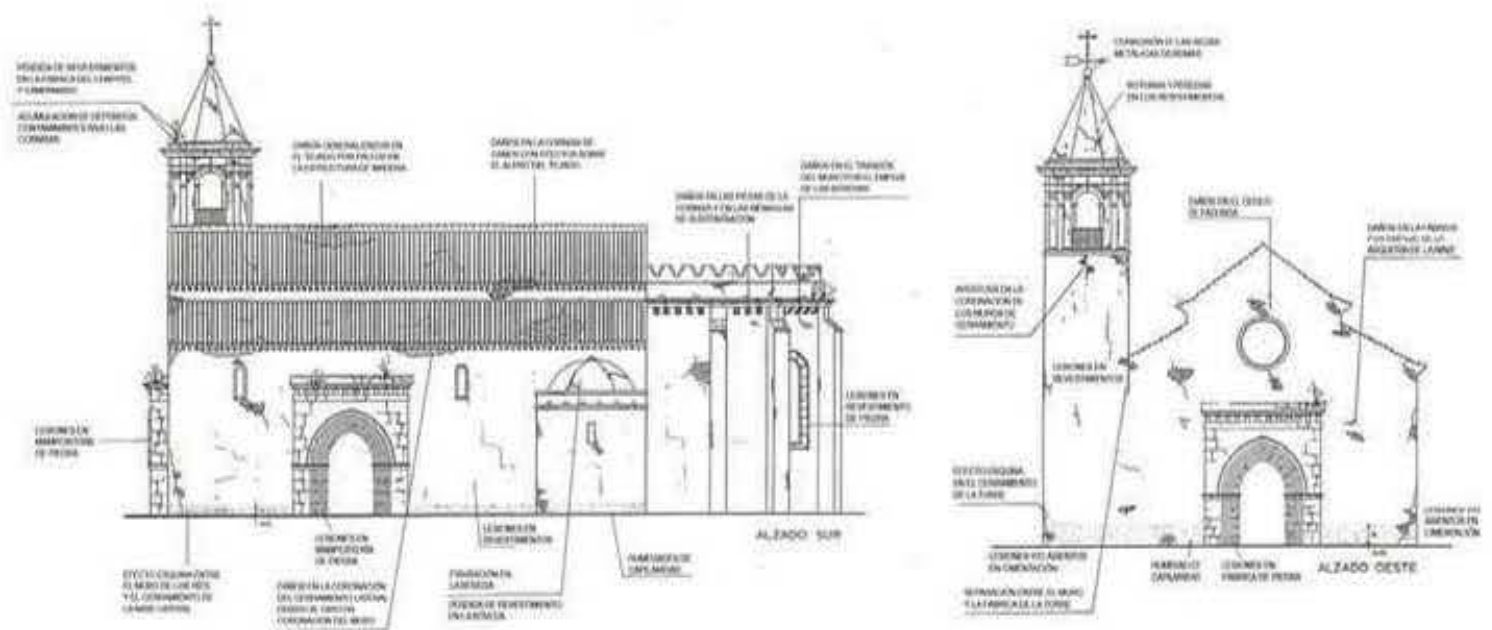

Figure 3. Typical damages of the model. Source: Vigil-Escalera, 1991.
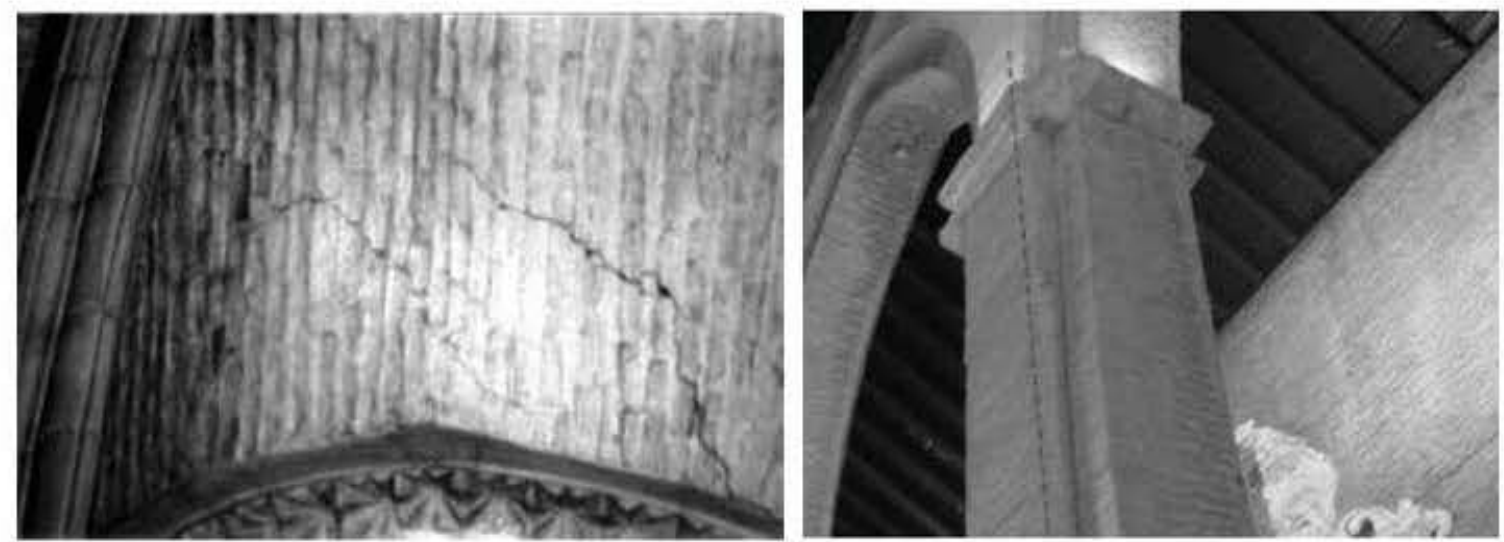

Figure 4. Cracks on the brick vaulted of the head and inclination of the pillars of the central nave. Source: author.

Apart from these typical damages it is interesting to make a brief study of the damages that could be specifically produced by an earthquake. Thus, the analysis of the damage caused by seismic events on buildings with a design scheme similar to the examples used and we have discussed above highlights the weaknesses of the model, being indicative to pre-evaluate the most risky zones where we should expect the highest accumulations of effort. Thus, damages are highlighted in the coronation of headwalls and gable wall, as well as the collapse of the side walls in those places where the connection between these and the cover has lost stiffness.

Therefore, the influence of the roof in the global structural behaviour facing dynamic actions are considered as essential. This is due to the damages because of the important horizontal displacement of the top of side walls that can induce significant stresses in the beams of the roof causing first its collapse and the bearing walls that support them after because of the losing of the bracing produced by the roof.

These points should be treated with special attention during the restoration process of the building.

Throughout the time, all examples studied have been suffered some reparations. Although they could be more or less successful, undoubtedly they have a strong involvement in the structural behaviour of the building. For this reason they must be known and taken into account, especially in cases where they have been a source of subsequent pathologies that have affected the structural system. It is possible to emphasize for example the actions on the foundation with micropiles or with bracing slabs at the base of the walls; the different methods of crack reparation of the walls; vaults with backing concrete; wooden roofs covering beth the central and lateral nave where have been usual place a concrete beam reinforcing the top of the walls. Also it 
is possible to find interventions which have supress the structural role of the wooden roof introducing a steel structure or by reconstructing the damaged parts of the wooden structure resistant elements.

\subsection{Technical inspection as a key issue for the characterization of bull ding}

To proceed in the right way in the rehabilitation process of these historic buildings is necessary to known its current construction state. To get this is fundamental making a technical inspection which should provide an adequate characterization of materials, damages and defining those specific elements that determine the structural resistance, including its state of conservation (Jaramillo, A. et al, 2005). Related to this it is compulsory making structural calculations and non-destructive in situ tests.

From the point of view of the analysis of the structural behaviour is considered very appropriate the finite elements method. To use this it is essential to characterize the model by defining the strength parameters of the materials that configure the structure for example the admissible stress and the elastic modulus.

Meanwhile, within the broad group of non-destructive tests, it has been revealed as essential the environmental vibration test because this allowed us to obtain an empirical value of the stiffness of the building and therefore define its ability to tesist horizontal actions.

\section{MODEL CHARACTERIZATION}

Technical inspection, as previously mentioned, has allowed a complete material characterization of the model. This fact is necessary to develop calculations based on finite elements method. Therefore, research is focused on defining foundations and its relationship with the soil. Also, definition of resistance parameters of brick walls and wooden roofs has been considered.

\subsection{Foundation}

Terrain located under buildings analysed has been studied by soil profiles. In this way, a standard soil profile has been obtained with information provided by several boreholes and the research document called "Geotechnical Map of Seville". The most relevant information has been provided by boreholes executed during restoration works on these buildings during the last three decades.

Table 1. Soil stratum considered.

\begin{tabular}{|c|c|c|c|c|c|c|c|c|c|c|}
\hline & \multicolumn{2}{|c|}{ Clay $(\mathrm{m})$} & \multicolumn{2}{|c|}{ Sand $(m)$} & \multicolumn{2}{|c|}{ Gravel (m) } & \multirow{2}{*}{$\begin{array}{c}\text { Loam } \\
\text { (m) } \\
\text { Top } \\
\end{array}$} & \multirow{2}{*}{$\begin{array}{c}\text { Phreatic } \\
\text { level } \\
\text { (m) }\end{array}$} & \multirow{2}{*}{-\{} & \multirow{2}{*}{ in. } \\
\hline & Top & Thickness & Top & Thickness & Top & Thickness & & & & \\
\hline $\begin{array}{l}\text { Minimum } \\
\text { value }\end{array}$ & $7^{\prime} 50$ & $7 ' 50$ & $11^{\prime} 00$ & $10^{\prime} 50$ & $15^{\prime} 50$ & 1475 & $28^{\prime} 75$ & $4^{\prime} 75$ & - & $6=$ \\
\hline $\begin{array}{l}\text { Maximum } \\
\text { value }\end{array}$ & $0^{\prime} 50$ & $0^{\prime} 00$ & 300 & $0^{\prime} 75$ & 600 & 675 & $14^{\prime} 75$ & $2^{\prime} 75$ & -1 & \\
\hline $\begin{array}{l}\text { Medium } \\
\text { value }\end{array}$ & $3^{\prime} 47$ & $4^{\prime} 19$ & $7^{\prime} 66$ & $2^{\prime} 90$ & $10^{\prime} 56$ & 925 & $19 ' 82$ & $3^{\prime} 56$ & -1 & ats \\
\hline
\end{tabular}

Relationship between buildings and terrain can be considered "fixed" or, like a "deformable foundation block". In this second calculation model, displacements are more important than efforts on constructive elements. It is due to consider that the building is supported by springs which increase deformations and reduce efforts produced by incidental seismic energy. 
Although most of researchers recommend "deformable foundation block" model, it is needed to calculate constant $\mathrm{K}$ value of the springs. This is not an easy issue due to lack of information: foundation levels and 30 meters deep boreholes are not usually known on this kind of historical buildings. Thus, buildings have been considered "fixed" on the ground and have been calculated by rigid solid model, a tried and tested method. In this way, effort values have been increased and results keep safe.

\subsection{Discontinues walls: brick walls and stone masonry}

There are two main theories that make possible the analysis of this type of constructive elements. First, the micro-models have their field of application in the study of the local behaviour of masonry structural details. They are used for example to study the behaviour of the interface or behaviour at specific points such as doors or windows. Moreover macro-models are used when the structure is formed by solid walls with sufficiently large dimensions that make the stresses across and along the elements substantially uniform. This is our case so an analysis using macro-models theories is made (López et al, 1998; Lourenço, 1995; Pérez, 2006). According to the results obtained using the theories developed by different authors, the evaluation of the elements of stone masonry and brick walls that have been characterized by the following values:

Table 2. Calculation values for brick masonry and stone masonry.

\begin{tabular}{ccccccccc}
\hline$\left(\mathrm{kN} / \mathrm{m}^{2}\right)$ & $\mathrm{E}_{\mathrm{x}}$ & $\mathrm{E}_{\mathrm{y}}$ & $\mathrm{E}_{\mathrm{z}}$ & $\mathrm{G}_{\mathrm{x}}$ & $\mathrm{G}_{\mathrm{y}}$ & $\mathrm{G}_{z}$ & $v$ & $\begin{array}{c}\rho \\
\left(\mathrm{kN} / \mathrm{m}^{3}\right)\end{array}$ \\
\hline $\begin{array}{c}\text { Brick } \\
\text { walls }\end{array}$ & 938.550 & 952.710 & 1.151 .800 & 427.910 & 436.550 & 505.250 & $0 \prime 25$ & $18^{\prime} 0$ \\
$\begin{array}{c}\text { Stone } \\
\text { masonry }\end{array}$ & 5.515 .340 & 5.566 .320 & 4.027 .100 & 702.240 & 729.260 & 852.440 & $00^{\prime} 30$ & $23^{\prime} 0$ \\
\hline
\end{tabular}

\subsection{Wooden roof}

The characterization of the wooden elements that define the roof it is made beginning from a historical analysis of the most common wood used in the buildings of the area. This has been verified from identification tests in the laboratory from samples taken in situ.

The results show that the wood used is Pinus sylvestris, which is characterized by the following parameters:

Table 3. Calculation values for wooden elements of the roofs.

\begin{tabular}{ccccccccc}
\hline$\left(\mathrm{kN} / \mathrm{m}^{2}\right)$ & $\mathrm{E}_{\mathrm{x}}$ & $\mathrm{E}_{\mathrm{y}}$ & $\mathrm{E}_{\mathrm{z}}$ & $\mathrm{G}_{\mathrm{x}}$ & $\mathrm{G}_{\mathrm{y}}$ & $\mathrm{G}_{\mathrm{z}}$ & $v$ & $\begin{array}{c}\rho \\
\left(\mathrm{kN} / \mathrm{m}^{3}\right)\end{array}$ \\
\hline $\begin{array}{c}\text { Pynus } \\
\text { Sylvestris }\end{array}$ & 7.000 .000 & 230.000 & 230.000 & 440.000 & 440.000 & 440.000 & 0 & 0 \\
\hline
\end{tabular}

\section{RESULTS OBTAINED}

\subsection{Calculation of model by the Finite Element Method}

Once developed the model and characterized the materials, previously to the calculation using the finite element method, defined the intensity of the earthquake to apply as external load. It has consider a VIII degree earthquake (EMS) due to History has demonstrate it is the most intensive earthquake that the region of Andalusia has suffered along the years (Justo, J. L. et al, 1998). This means consider an acceleration $a_{b}=0,15$ instead of $a_{b}=0,07$ as is indicated in the Spanish Seismic Code NCSE-02. 
With these data, once the calculation has been developed both principal stress in each of the resistant elements (walls and roofs) and main deformations and displacements are obtained.
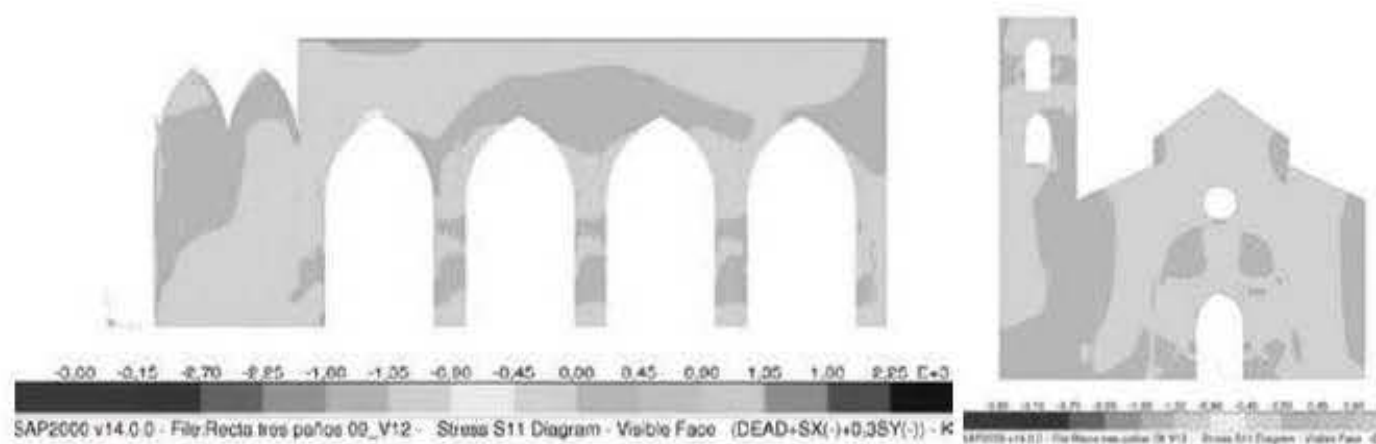

Figure 5. Main stress diagram on the bearing wall of the central nave and on the gable wall. Source: author.

It is significant that in any case the values of admissible stresses in compression are supported by the brick walls. However the tensile stress are overcome this admissible tension on some areas that are unable to resist the stress generated. These points are located in the centres of the side walls, the headwalls, the gable walls, the central arches, pillats and at the joints between side walls and headwalls or gable walls.

With respect to the stresses transmitted to the beams of the wooden roof, it was verified that in that areas with highest stress values is not exceeded the admissible stress of the wood.

Furthermore the stress state, it is particularly interesting to study the maximum displacements. These occur at the top of the gable wall, at the top of the central arches and the top of the tower.
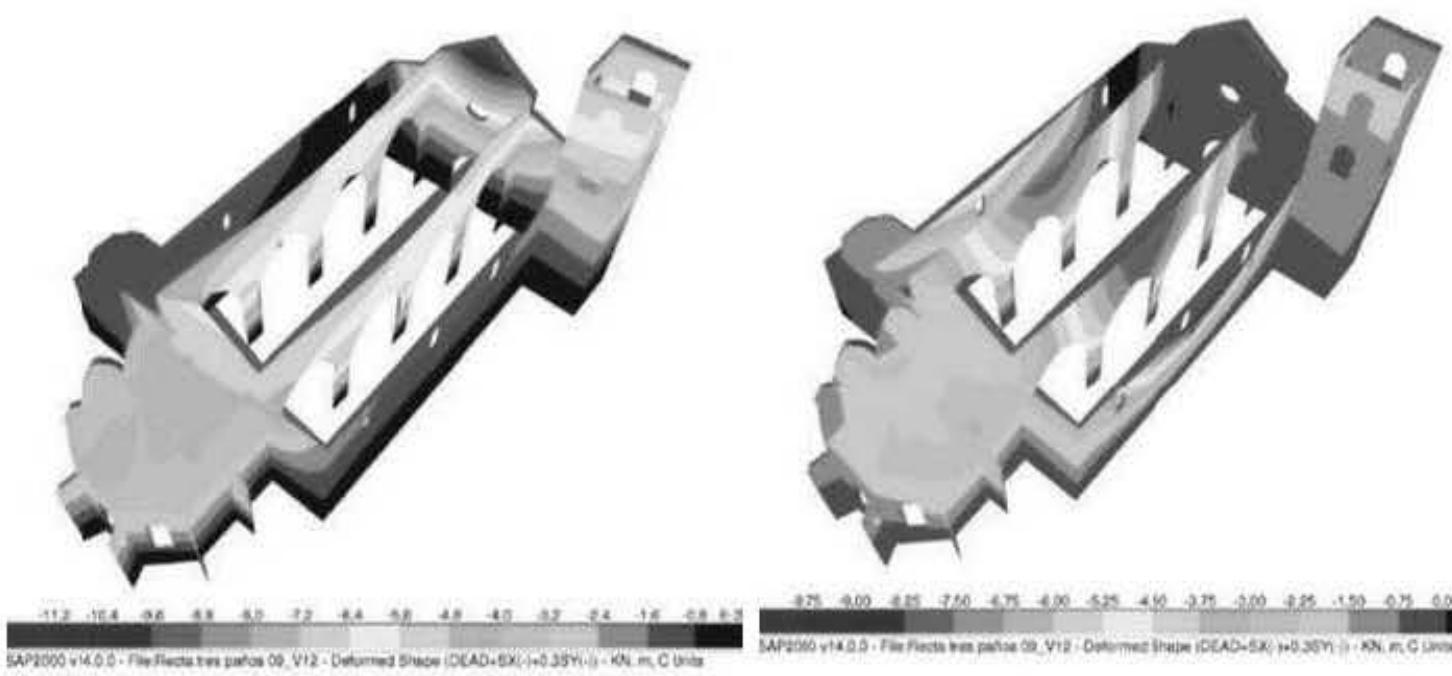

Figure 6. Main horizontal displacements on the 3D model (longitudinal and transversal direction). Source: author.

\subsection{Environmental vibration measures}

Ambient vibration tests have been developed in a similar model to those studied in Seville but located in the town of Utrera (Seville). These tests were carried out during the restoration works and after the end of the works in order to obtain the natural period of the structure of the model. Due to the similarities between the buildings, these values were compared with those obtained using the finite element computer program and the results of analytical estimations based on the 
simplified formulation included on different regulations (Peru, Dominican Republic, ...) and on the Spanish one.
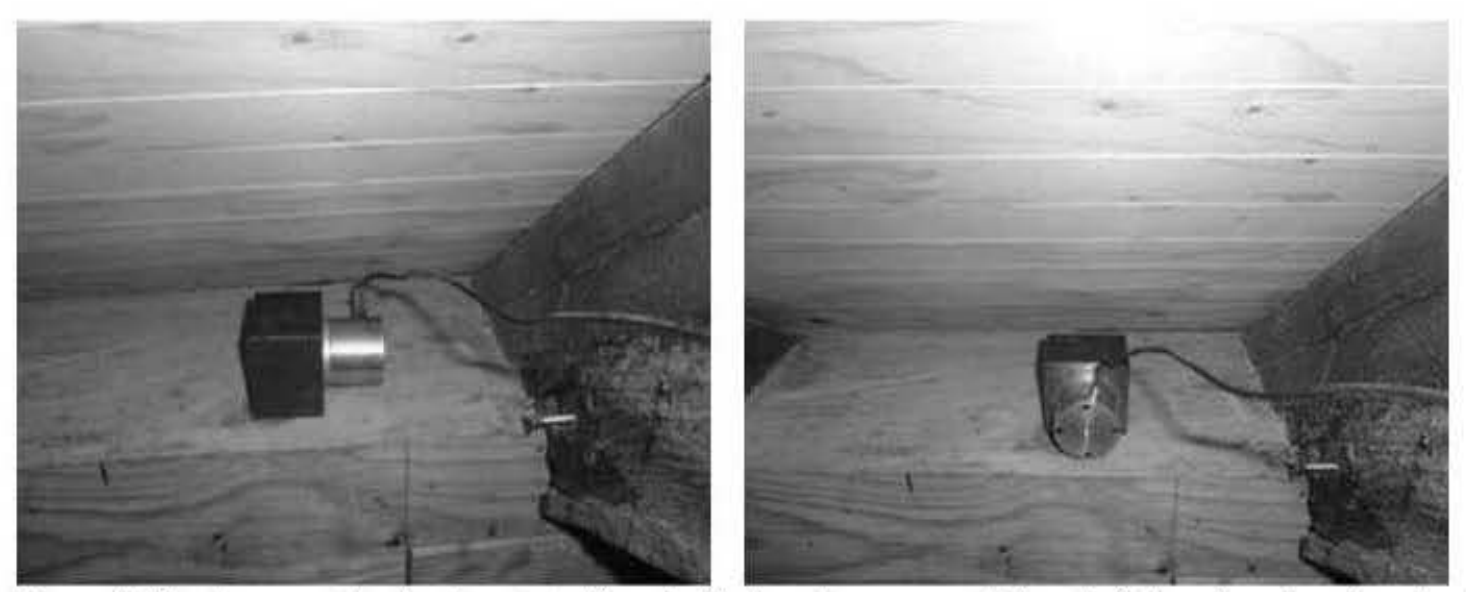

Figure 7. Environmental vibration tests (longitudinal and transversal direction) developed on the church of the convent of the Carmelites (Utrera, Seville). Source: author.

According to the calculation model, the frequency ranges varying from 2 to $5 \mathrm{~Hz}$. According to Spanish law, should be between 6 and $20 \mathrm{~Hz}$ for this type of buildings. These values would be between 4 and $10 \mathrm{~Hz}$ according to the average values obtained from the analysis of other regulations (Dominican Republic, Cuba and Peru). Therefore, the logic values would be between 2 and $20 \mathrm{~Hz}$. This range, although it is broad, it locates us around the result we should expect from the in situ test which is especially important to exclude unusual results.

The in situ tests have shown that we are in the range noted above. To settle on respect to other values as possible options, we have compared on the table below this results with the values obtained from the Finite Elements Method Calculation and those coming from the application of the codes.

Table 4. Comparison between the periods and frequencies obtained using different methods.

\begin{tabular}{|c|c|c|c|}
\hline & & Period $T_{p}(s)$ & Frequency $(\mathrm{Hz})$ \\
\hline \multirow{2}{*}{$\begin{array}{c}\text { Various Codes } \\
\text { (medium values) }\end{array}$} & Long. & $0^{\prime} 12$ & $8^{\prime} 03$ \\
\hline & Trans. & $0^{\prime} 17$ & 5,99 \\
\hline \multirow{2}{*}{$\begin{array}{c}\text { NCSE-02 } \\
\text { (Seismic Spanish } \\
\text { Code) }\end{array}$} & Long. & $0^{\prime} 07$ & $15^{\prime} 0$ \\
\hline & Trans. & $0^{\prime} 10$ & $9 \cdot 50$ \\
\hline FEM Calculation & & 0'51 (mode l) 0'20 (mode 12) & 1'94 (mode 1) 5'20 (mode 12) \\
\hline In situ tests & $\begin{array}{l}\text { Long. } \\
\text { Trans. }\end{array}$ & $\begin{array}{l}0,082 \\
0,105\end{array}$ & $\begin{array}{l}12^{\prime} 16 \\
y^{\prime} 48\end{array}$ \\
\hline
\end{tabular}

It is possible to observe that the values obtained for in situ period are below the maximum value marked by the codes so we can consider that the repaired and undamaged building has the necessary stiffness conditions. Moreover if the stiffness conditions are adequate does not imply that the building support the stresses coming from the seismic action. Due to this the building needs to be reinforced at those zones where these admissible tensions could be surpass, particularly on tensile stress.

Differences between the estimated periods and those obtained from in situ testing lower of $10-20 \%$ may be acceptable. A difference upper from $20 \%$ indicate important structural damages. Values of periods measured in situ, in some cases, 10 times higher than estimated, can make even perceptible the vibrations of the structure itself. In these cases it is almost compulsory the adoption of appropriate measures to make sure the stability of the building. According 
to different authors, it is common that the frequency is between 2 and $10 \mathrm{~Hz}$, so that the period vary between 0,10 and $0,50 \mathrm{~s}$.

\section{CONCLUSIONS}

The generation of a model about the constructive typology as well as the characterization of the materials has made the computer modeling and subsequent structural analysis by finite element method possible. This calculation process gives us sufficiently accurate information about how the structure behaves under a virtual seismic effort and has been proved complementary to the ambient vibration test. This is because the first one gives a numerical estimation about the structural behavior and the second one allows the empirical testing of the values we have previously estimated by analytical methods.

These calculations have shown a result that present how compressions are generally absorbed by the walls, not surpassing its estimated capacity limit. On the contrary, we have obtained different areas where the allowable tensile values are exceeded. This would imply to adopt the necessary reinforcement measures in these areas.

To avoid damages that could be derived from the seismic action and could cause the ruin of the analyzed buildings, we proposed a reinforce system based on the use of fiber carbon bands to absorb the generated tensile strength and simultaneously an effect of spiral reinforcement as a bandage on all the walls around the building avoiding structural failures.

In order to reduce the displacement and prevent the overturning of the triangular pediments on the gable and on the head wall, we proposed the introduction of a set of ties rod arranged on the plane of the pitch of the roof and anchored on the abutment and on the capstone on the respective walls.

The movement of the side walls is reduced by bracing them in the rafter and collar tie roof system placed over the nave and on the aisles.

From the point of view of the wooden roof on the central nave, its own design and constructive system assure a homogeneous behavior and global deformation against the incidence of a horizontal action as a huge trussed joist thanks to the bracing elements that conform it.

The obtained results guarantee the use of the environmental vibration test to determinate the natural frequency of a building as previously as subsequently to restoration works. From these values it is possible to estimate the horizontal bracing of the building and verify if works made have had the desired reinforcement effect. In our case, it has been verified how the own period of the church, once the works were finished, had approximately the same value as the obtain using analytical methods or even slower. This demonstrates the increase of the safety index of the building under horizontal actions.

Elements such as the apse and the tower behave as rigid cores reducing the effective length of the side walls and therefore reducing their final deformations. The historical introduction of these elements attached to the main body of the church increase the safety index of the buildings against an earthquake.

In general, the results shown the good behavior of this type of structures against an earthquake both by its own design and by thickness adopted for the constructive elements. This question is clearly demonstrated by its survival today even having been exposed to high-intensity earthquakes that have affected them throughout its history. Even so, a good maintenance program and the adoption of specific reinforcement measures on futures intervention processes is revealed as crucial to eliminate the punctual weaknesses the typology has shown during the analysis process.

\section{REFERENCES}

Angulo Íñiguez, D. 1983. Arquitectura Mudéjar Sevillana de los Siglos XIII, XIV y XV. Sevilla: Ayuntamiento de Sevilla.

Cómez Ramos, R. 1974. Arquitectura alfonsí. Sevilla: Diputación Provincial de Sevilla. 
Espinoza, F. \& Canas, J. A. \& Pujades, L. G. 2000. Utilización de la vibración ambiental como fuente de excitación para el cálculo de periodos fundamentales de edificios. Madrid: Ministerio de Fomento, Dirección General del Instituto Geográfico Nacional.

García Arribas, R. 2002. El peligro sísmico en Andalucía. Málaga: INDYCCE, COAAT Málaga.

Jaramillo Morilla, A. \& Huete Fuertes, R. \& Rodríguez Liñan, C. 2005. Protocolo de Inspección Técnica de Edificaciones ITE. Sevilla: Colegio Oficial de Arquitectos de Sevilla.

Justo Alpañés, J. L. \& Jaramillo Morilla, A. \& Gentil Govantes, P. 1998. Comportamiento de los monumentos de Sevilla bajo la acción de los terremotos. Ingeniería civil Journal, n 109: 5.

López, J. \& Oller, S. \& Oñate, E. 1998. Cálculo del comportamiento de la mampostería mediante elementos finitos. CIMNE Monograph n 46. Barcelona: CIMNE.

Lourenço, P. B. 1995. The elastoplastic emplementation of homogenisation techniques with an extension to masonry structures. Report n 03-21-1-31-02, Delft (the Netherlands): Delft University of Technology.

Norma de Construcción Sismorresistente Española (NCSE-02). 2002. Madrid: Ministerio de Obras Públicas y Transportes.

Pérez Aparicio, J. L. 2006. Técnicas de rehabilitación de edificios históricos. Unpublished notes from Doctoral course.

Vigil-Escalera, M. 1991. Iglesias mudéjares sevillanas de los siglos XIII, XIV y XV. Unpublished Doctoral Thesis. 